PRODUCTION

ENGINEERING ARCHIVES
2015, Vol. 6, No 1, pp 30-34

ISSN 2353-5156

ISSN 2353-7779 (print version)

(online version)

\title{
Hemocompatibility of ultrafine systems on the basis of chitosan and its derivatives polymer- colloid complexes
}

\author{
M.V. Bazunova ${ }^{1}$, E.I. Kulish ${ }^{1}$, R.F. Tukhvatullin ${ }^{1}$, L. A. Sharafutdinova ${ }^{1}$, V.G. Shamratova ${ }^{1}$, \\ D. Klimecka-Tatar ${ }^{2}$, G.E. Zaikov \\ ${ }^{1}$ Bashkir State University 32 Zaki Validi Street, 450076 Ufa, Republic of Bashkortostan, Russia \\ ${ }^{2}$ Institute of Production Engineering, Czestochowa University of Technology, Armii Krajowej 19B, 42-201 Czestochowa, Poland \\ ${ }^{3}$ Institute of Biochemical Physics named N.M. Emanuel of Russian Academy of Sciences, Kosygina Street, 119334, Moscow, Russia
}

\begin{abstract}
This article presents the results of the development process for the preparation of micro and nano-sized polymer-colloid complexes (PCC) on the basis of water-soluble natural polymer chitosan (CTZ) and the sodium salt of chitosan succinylamid (SCTZ) with silver halide sols in aqueous media. Results of research of CTZ, sodium salt of SCTZ solutions and PCC of CTZ and SCTZ with colloidal particles of silver iodide influence on structurally-functional properties of erythrocytes' membranes on model of acidic hemolisis are presented in the article. Their influence on the nature of erythrocytes distribution by degree of their stability and on kinetic parameters (the beginning, intensity and completion of process of their destruction) under the influence of the damaging agent ( $\mathrm{HCl}$ ) is shown. The comparative analysis of results convinces that CTZ, SCTZ solutions and disperse systems on the basis of PCC of CTZ and SCTZ with colloidal particles of the silver iodide are capable of modulating variously matrix properties of erythrocytes of blood.
\end{abstract}

Key words: colloidal complexes, chitosan, micelles of silver iodid, hemocompatibility, acid resistance of erythrocytes

\section{Introduction}

The problem of creating stable disperse systems based on lyophobic sols stabilized by non-covalent interaction of colloidal particles with macromolecules of natural and synthetic polymers is topical in the following task: synthesis of metal nanoparticles in polymer-protectors solutions; creation of metal-polymer nanocomposites with unique catalytic, electrical, optical and magnetic properties (ELISEEVA E.A. 2014); obtaining of nano- and micro-sized polymeric containers for targeted delivery of slightly soluble drugs (BAZUnova M.V. 2014, Bolotova G.V. 2010).
Use of ultrafine systems is especially effective while introducing new ways to target delivery of drugs to the affected area of the body and new methods of prolonging the therapeutic effect of drugs. As a means of target delivery of drug with prolonged action nanosized systems based on natural and synthetic biodegradable biocompatible polymers, including chitosan (CTZ) and its derivatives are often used.

The positive charge of CTZ macromolecules promotes its penetration through cell membranes and dense layers of the epithelium, provides good adhesion to mucosa and determines its bacteriostatic properties.

Spontaneously formed aggregates of macromolecules of CTZ and its derivatives are arousing particular 
interest during the creation of drug carriers based on these polysaccharides. It is possible to obtain polymeric carriers with the desired size directly knowing the laws of aggregates of CTZ and its derivatives formation, and the factors that determine their size. However, the experimental data available are contradictory. There is also evidence of instability of associated systems based on CTZ and its derivatives (KORCHAGINA E.V. 2012).

The size of polymeric nanoparticles for targeted drug delivery is equally important. It is known that polymeric carriers with sizes of 100 - $200 \mathrm{~nm}$ may provide directional transportation of antituberculosis drugs directly into macrophages, as macrophages are capable of absorbing foreign objects exactly with such sizes (Bolotova G.V. 2012). Particles of a smaller size (30-40 nm to $200 \mathrm{~nm}$ ) can accumulate passively in antitumor foci by a mechanism known as increased permeability and retention. This happens because of the increased blood supply and lower lymphatic drainage in a tumor (NEL A.E. 2009).

One of the approaches for establishing stable nanostructured systems with adjustable sizes may be using the ability of macromolecules to self-assemble by intermolecular association via non-covalent bonds with the example of a CTZ and its derivatives polymer-colloid complexes (PCCs), such as sodium salt of chitosan succinylamide (SCTZ) with inorganic colloidal particles of lyophobic sols, e.g., sol of silver iodide. The proposed approach is interesting because: the resulting complexes may retain aggregate stability for a long time, that allows the prediction of the possibility of practical application of composites and inorganic colloidal particles of lyophobic sols can act as nucleus for encapsulation of slightly soluble drugs by using nano- and micro-sized containers (INOZEMCEVA O.A. 2007).

An additional advantage of developing methods of targeted delivery of drugs based on the PCC of CTZ and SCTZ with colloidal particles of silver iodide is antiseptic properties of AgI.

Colloidal systems of drugs' delivery are usually designed both for oral and intravenous administration of drugs (LAMPREHT ALF. NANOLEKARSTVA). Therefore, the study of the biocompatibility of initial polysaccharides CTZ and SCTZ solutions and aqueous dispersions of PCCs of CTZ with blood cells gains special importance. Blood, as one of the body fluids, serves as a kind of informative biomarker for organism resistance to the action of various factors, allowing establishment of the critical points of transition from a pronounced toxic to the stimulating effect. Erythrocytes, like other blood cells respond to changes in the external and internal environment, but due to the morphological simplicity their pathological reactions are slightly informative. Due to this, the action of certain chemicals in subtoxic doses, usually does not cause microscopically observed changes. However, one of the manifestations of their influence may be changes in cell resistance to the effects of hemolytic agents. Dysfunction of biological membranes under the influence of various exogenous substances is in many cases not only the result, but the cause of pathological changes in the cell and the organism as a whole (SAVLUKOV A.I. 2011).

In connection with the foregoing, it is appropriate to obtain the PCC on the basis of water-soluble natural CTZ and SCTZ polymers with silver halide sols in aqueous media and to study the influence of the sample of CTZ, SCTZ solutions and the resulting dispersion PCC on the structural and functional properties of erythrocyte membranes. Taking into account that the main reaction of erythrocytes in contact with a foreign surface is lysis (SEVAST'Y YANOV V.I. 1987), as a model for evaluating the effects of these drugs on cells acid hemolysis.

\section{Experimental}

In the research the CTZ samples with deacetylation degree of $82 \%$ and $\mathrm{Mw}=80000$ a.m.u. and SCTZ with $\mathrm{Mw}=207000$ a.m.u. with the substitution degree of $75 \%$ were used (produced by "Bioprogress" Russia, Shchelkovo).The crossover concentration of CTZ and SCTZ determined from the dependence of logarithm of polysaccharides solutions dynamic viscosity on the concentration logarithm was $0.4 \mathrm{wt} \%$. and $0.7 \%$ wt \%. respectively.

AgI sols prepared by standard methods from $7 \mathrm{ml}$ of $0.01 \mathrm{~N}$ silver nitrate solution and $10 \mathrm{ml}$ of $0.01 \mathrm{~N}$ potassium iodide.

The initial AgI micelle particles' size, defined by two independent methods - turbidimetry at a wavelength of 440 and $490 \mathrm{~nm}$ by FEC-56 instrument, and 
by particle size analyzer (Shimadzu Salid - 7101) was between 95 and $120 \mathrm{~nm}$.

Disperse systems on the basis of SCTZ PCC with colloidal particles of silver iodide are obtained by mixing of an aqueous solution of SCTZ with $0.4 \%$ concentration with freshly prepared AgI sol in volumetric ratio of 1:1 and 2:1 (hereinafter - 1:1 SCTZ:AgI sol and 2:1 SCTZ:AgI sol).

Disperse systems on the basis of CTZ PCC with colloidal particles of silver iodide are obtained by mixing of CTZ dissolved in 1\% acetic acid with concentration of 1 wt.\% with freshly prepared AgI sol in volumetric ratio of 1:1 (hereinafter - 1:1 CTZ:AgI sol).

The 1:1 SCTZ:AgI sol, 2:1 SCTZ:AgI sol and 1:1 CTZ:AgI sol dispersions particles' size defined by the particle size analyzer (Shimadzu Salid - 7101) is between 100 and $375 \mathrm{~nm}$.

Quantitative studies of CTZ and SCTZ complexes with AgI micelles are carried out by turbidimetric titration of AgI sols by polymers' solutions so that the $\left[\mathrm{Ag}^{+}\right]$: unit of the polymer ratio is from $0.175: 1$ to $2: 1$.

Rheological measurements of CTZ, SCTZ solutions and PCC dispersion conducted on a modular dynamic rheometer Haake Mars III at $25^{\circ} \mathrm{C}$. Flow curves and viscosity curves were obtained in a constant shear stress mode at a shear rate of 0.1 to $100 \mathrm{~s}^{-1}$.

The influence of solutions CTZ, SCTZ and disperse systems based on CTZ and SCTZ PCCs with colloidal particles of silver iodide on the structural and functional properties of erythrocyte membranes was estimated by recording the kinetics of acid hemolysis. In the in vitro experiment, blood of $0.5 \mathrm{ml}$ was used, obtained from the tail vein of Wistar $(n=20)$ rats weighing 200-250g in compliance with the European Convention requirements for the Protection of Vertebrate Animals used for experimental and other scientific purposes (Strasbourg, 1986) and the Russian Federal Law "On Protection of Animals on Cruelty" from 01.01.1997. Heparin is used as anticoagulant. Study of the influence degree of ultrafine systems on the basis of chitosan and its derivatives on the physicochemical properties of the lipid-protein complexes of the plasma membranes was performed on the model system CTZ sample-erythrocytes- $\mathrm{HCl}$ due to erythrocyte resistance change because of influence of hydrochloric acid ( 0.08 $\mathrm{ml}$ ) in iso-osmotic solution of $\mathrm{NaCl}(0.85 \%)$. Hemolysis was carried out in quartz cuvettes with exterior dimensions of $20 \times 40 \times 10 \mathrm{~mm}$ and a volumetric displacement of $5 \mathrm{ml}$. Initial AgI sol, aqueous solution of SCTZ with concentration of 0.2 wt. \%, CTZ dissolved in $1 \%$ acetic acid with concentration of 0.5 wt.\%, aqueous dispersion of 1:1 SCTZ:AgI sol and 2:1 SCTZ: AgI sol, 1:1 CTZ: AgI sol are used as active agents. Hemolysis intensity in time recorded photometrically using photoelectrocolorimeter KFK - 3. Determination of extinction was performed every 15 seconds until no further changes. Reducing of extinction - result of the gradual destruction of red blood cells, and those cells are first broken, which have weaker resistance to hydrochloric acid. According to the obtained values acidic erythrograms depicting the distribution of erythrocytes by resistance were built: on the horizontal axis - hemolysis time, which is a measure of the resistance, delayed, the vertical axis - the percentage of erythrocytes. In the control, the differential distribution curve of erythrocytes by resistance takes the form of unimodal curve with steeply descending branch. Analysis of the kinetics of acidic erythrograms performed using the following parameters: start time, end time and the peak of hemolysis, the width of the interval of the dominant group of erythrocytes in the population. The proportion of cells with different resistance in the general population of erythrocytes was calculated

Mathematical and statistical analysis of the results was carried out in the application package STATISTICA v. 7.0 (StatSoftInc, USA). Comparison of acidic erythrograms was performed using the nonparametric Mann-Whitney test, the null hypothesis of no difference was rejected at $\mathrm{p}<0.05$.

\section{Results and discussion}

The method of achieved results - experiment, the case study should to be understandable for the reader (after completion the knowledge) such that it could be undertaken independently.

The particle sizes of initial AgI micelles, defined according to the turbidity data and measurement using a particle size analyzer (Shimadzu Salid - 7101) are, on average, 95-120 nm. Consequently, one can expect the formation of polycomplexes on the basis of AgI sols with water-soluble polymers having a particle size close to the nanometer range. 
To find the critical molar ratio of $\left[\mathrm{Ag}^{+}\right]$: polysaccharide unit, leading to the formation of an insoluble complex, the turbidimetric method was used at polymer concentrations below the crossover point to avoid the mutual influence of macromolecular coils. The results are shown in Figure 1.

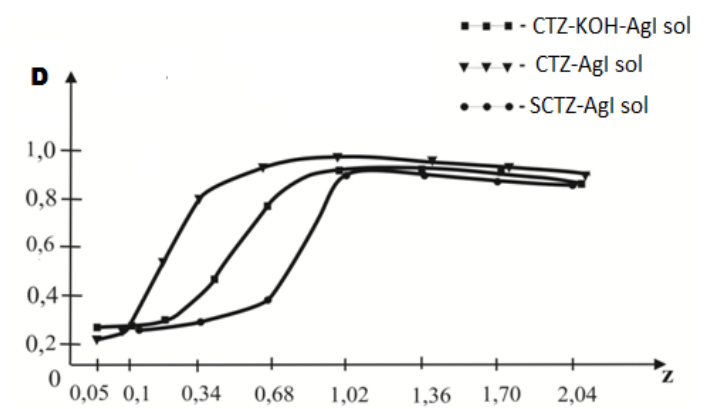

Fig.1. The dependence of the optical density of mixtures of CTZ solutions with AgI sol, of CTZ solutions in the presence of $0.01 \mathrm{~mol} / \mathrm{I} \mathrm{KOH}$ with AgI sol, of SCTZ solutions with AgI sol on composition of the mixture $\mathrm{Z}=\left[\mathrm{Ag}^{+}\right] /$[polymer unit] at $\mathrm{t}=20^{\circ} \mathrm{C}, \mathrm{I}=490 \mathrm{~nm}$.

It has been established that for PCC on the basis of SCTZ and AgI sol range of molar ratios wherein aggregate stability of the particles observed is larger than for systems based on CTZ- AgI sol and even particularly neutralized CTZ- AgI sol. This can probably be attributed to the higher density of the CTZ charge distribution on the polysaccharide macromolecules and high ionic strength of solution.

In any case, it was found that the addition of a weak polyelectrolyte increases sedimentation stability of AgI micelles. The particle sizes of obtained PCC on the basis of SCTZ solution mixtures with AgI sol, ranging from 100 to $375 \mathrm{~nm}$.

A significant increase in the dynamic viscosity SCTZ:AgI sol system at middle concentrations that are lower in comparison with SCTZ's (Fig. 2) indicates the formation of the PCC and the structuring effect of AgI particles in SCTZ:AgI systems.

The results of studies on the hemocompatibility (Table. 1) showed that the studied solutions of samples of CTZ, SCTZ and PCC dispersions of CTZ and SCTZ with colloidal particles of silver iodide have an ambiguous effect on the functional state of the rat blood cell membranes. Comparative analysis confirms that the tested samples are capable of changing the character of the distribution of red blood cells in terms of their stability and kinetic parameters of hemolysis in different ways. Particularly $0.2 \%$ SCTZ solution had no significant effect on the initial capacity of red blood cells to resist the action of hemolytic agent. At the same time, a sample of the disperse system of 2:1 SCTZ: AgI sol discovered the ability to change the functional state of erythrocyte membranes. During all periods of observation the destruction intensity of red blood cells by the action of hydrochloric acid and the total lysis duration markedly differed from the original characteristics, increased for resistant erythrocytes. Apparently, this SCTZ composition has a stabilizing effect on the erythrocyte membranes.

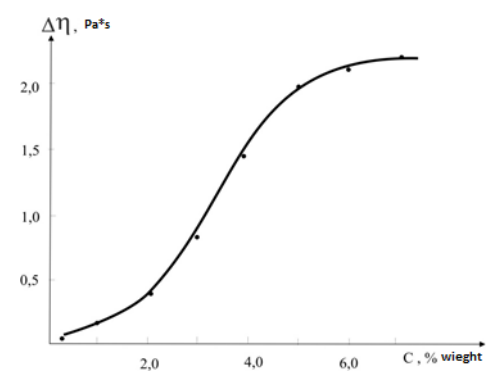

Fig. 2. Increase of the dynamic viscosity of the SCTZ: AgI sol system in comparison with solution SCTZ with the polymer concentration increasing, 200C, AgI particle concentration of $0,004 \mathrm{~mol} / \mathrm{l}$

Estimating the resistance degree after the incubation of red cells with dispersion of 1:1 HTZ:AgI sol, it should be noted that despite the slight decrease erythrocyte fraction with average stability (41.6\%), the number of red blood cells with a high and increased stability in comparison with the control (24 $6 \pm 2,9 \%$ and 21,2 $\pm 2,9 \%$ respectively, $\mathrm{p}<0,01$ ) significantly increases. More later involvement of red blood cells in the process of hemolysis was found, that could indicate a protective effect of the compound.

Comparison of study results of the effect of ultrafine systems based on chitosan and its derivatives on the integrity of red blood cells demonstrated the ability of some (2:1 SCTZ: AgI sol, 1:1 CTZ: AgI sol, 1:1 SCTZ: AgI sol) to provide a stabilizing effect on the membrane of red blood cells and others $(0.2 \%$ aqueous SCTZ solution) to cause a decrease in resistance of erythrocytes. The observed effects may be determined by the variety of features of their impact on the nature of the bonds between the protein and lipid components of the membrane, the level of activity of cell enzyme systems and the value of the negative charge of the membrane surface (KALAWNIKOVA I.V. 2008). 
M.V. Bazunova, Hemocompatibility of ultrafine systems on the basis of chitosan..., Vol. 6(1)/2015

Table 1. Indicators of acidic resistance of erythrocytes in the control group and after exposure of chitosan (CTZ) solutions, sodium salt of chitosan succinylamide (SCTZ) and polymer-colloid complexes (PCCs) of CTZ and SCTZ with colloidal particles of silver iodide $(M \pm m)$

\begin{tabular}{|c|c|c|c|c|c|c|}
\hline Indicators & Control & $\begin{array}{l}0,2 \% \mathrm{SCTZ} \\
\text { solution }\end{array}$ & $\begin{array}{c}0,5 \% \text { CTZ solution in } \\
1 \% \text { acetic acid }\end{array}$ & $\begin{array}{l}\text { The aqueous } \\
\text { dispersion of 2: } 1 \\
\text { SCTZ: Agl sol }\end{array}$ & $\begin{array}{l}\text { The aqueous } \\
\text { dispersion of 1: } 1 \\
\text { SCTZ: Agl sol }\end{array}$ & $\begin{array}{l}\text { The aqueous } \\
\text { dispersion of } 1: 1 \\
\text { CTZ: Agl sol }\end{array}$ \\
\hline Time of the beginning of hemolysis, min & $0,5 \pm 0,01$ & $1,00 \pm 0,1$ & $1,5 \pm 0,4$ & $1,00 \pm 0,1$ & $1,5 \pm 0,2$ & $1,5 \pm 0,3$ \\
\hline Time of the ending of hemolysis, min & $5,5 \pm 0,1$ & $6,5 \pm 0,2$ & $6,5 \pm 0,4$ & $6,5 \pm 0,3$ & $6,5 \pm 0,2$ & $6,5 \pm 0,4$ \\
\hline Peak of thr acidic erythrogram, $\mathrm{min}$ & $2,00 \pm 0,3$ & $2,00 \pm 0,1$ & $2,00 \pm 0,1$ & $3,00 \pm 0,2^{*}$ & $2,0 \pm 0,1$ & $3,00 \pm 0,2^{*}$ \\
\hline Erythrograms base width, min & $5,00 \pm 0,1$ & $5,5 \pm 0,18$ & $5,00 \pm 0,2$ & $5,5 \pm 0,1$ & $5,0 \pm 0,2$ & $5,5 \pm 0,3$ \\
\hline $\begin{array}{l}\text { The percentage of highly resistant } \\
\text { erythrocytes, } \%\end{array}$ & $12,9 \pm 1,6$ & $11,5 \pm 1,4$ & $13,16 \pm 2,1$ & $34,1 \pm 4,7^{*}$ & $24,9 \pm 3,8^{*}$ & $24,6 \pm 2,9 *$ \\
\hline $\begin{array}{c}\text { The percentage of erythrocytes with } \\
\text { increased stability,\% }\end{array}$ & $4,78 \pm 0,31$ & $8,6 \pm 1,1 *$ & $6.96 \pm 0,8$ & $19,1 \pm 2,6^{*}$ & $13,00 \pm 2,1^{*}$ & $21,2 \pm 2,9 *$ \\
\hline $\begin{array}{l}\text { The percentage of erythrocytes with } \\
\text { average stability, } \%\end{array}$ & $73,19 \pm 5,86$ & $63,3 \pm 4,7$ & $72,5 \pm 5,2$ & $35,8 \pm 3,7^{*}$ & $52,3 \pm 4,6^{*}$ & $41,6 \pm 4,1^{*}$ \\
\hline $\begin{array}{l}\text { The percentage of erythrocytes with } \\
\text { low stability, } \%\end{array}$ & $9,13 \pm 0,87$ & $16,6 \pm 1,4^{*}$ & $7,38 \pm 0,6$ & $11,0 \pm 1,8$ & $11,29 \pm 2,3$ & $12,6 \pm 2,5$ \\
\hline
\end{tabular}

Taking into account that the acid resistance of erythrocytes is mainly determined by erythrocyte membranes phospholipid bilayer state, it can be assumed that the observed effects are specified by reorganization of the lipid component of erythrocytes membranes under the exposure of ultrafine systems on the basis of chitosan and its derivatives.

\section{Conclusion}

Thus, the method of obtaining stable nano- and micro-sized PCCs on the basis of water soluble natural polymers CTZ and SCTZ with sols of silver halide in aqueous media was developed. It was found that CTZ and SCTZ solutions and dispersions of polymercolloid complexes of CTZ and SCTZ with colloidal particles of silver iodide have a stabilizing or destabilizing effect on erythrocyte membranes depending on the composition of the sample, that shows their different hemocompatibility and points on the urgency of further search of chitosan its and derivatives complexes with inorganic colloidal particles having potentially protective properties. The results of these studies are promising for obtaining nano- and micro-sized polymeric containers for targeted delivery of slightly soluble drugs.

\section{References}

1. Bazunova M.V., Kolesov S.V., Hairullina A.I., Zaikov G.E. Podhod k sozdaniyu lekarstvennyh sredstv prolongirovannogo deistviya na osnove uglerod-polimernyh nositelei. Vestnik Kazanskogo tehnologicheskogo universiteta, 2014, vol.17, № 7, p. 145-147.
2. Bolotova G.V. Polimernye nositeli dlya protivotuberkulyoznyh lekarstvennyh sredstv na osnove hitozana// Molodoi uchenyi, 2010. Vol.2., №5, p. 208-210

3. Bolotova G.V. Polimernye nositeli dlya protivotuberkulyoznyh lekartsvennyh sredstv na osnove hitozana.//Molodoi uchyonyi, № 5 (16), vol. 2,

4. Eliseeva E.A., E.A. Litmanovich, G.YU. Ostaeva, E.V. Chernikova, I.M. Papisov. Zoli medi, stabilizirovannye polietilenglikol'-600-monolauratom i ego kompleksami s poliakrilovoi kislotoi. Vysokormolekulyarnye soedinenieya. Seriya A, 2014, vol. 56, № 6, p. 631-637

5. Inozemceva O.A. Formirovovanie i fiziko-himicheskie svoistva polielektrolitnyh nanokompozitnyh mikrokapsul// Rossiiskie nanotehnologii, 2007, vol.2, № 9, p. 6880

6. Kalawnikova I.V, Mehanizmy vzaimodeistviya antibiotikov penicilinovogo ryada $\mathrm{s}$ eritrocitami cheloveka//Byull. Eksp biologii i mediciny, 2008, vol. 146, № 10, p.419-423.

7. Korchagina E.V. Agregaciya hitozana i ego proizvodnyh $\mathrm{v}$ razbavlennyh vodnyh rastvorah: avtoreferat dissertacii kandidata fiziko-matematicheskih nauk: 02.00.06.: M.: MGU im. M.V. Lomonosova, 2012., p. 232

8. Lampreht Alf. Nanolekarstva. Koncepcii dostavki lekarstv v nanonauke. M.: Nauchnyi mir, 201, p. 232

9. Nel A.E., L. Madler, D. Velegol. Understading biophysicochemical interactions at the nan-bio interface// Nature Materials/ 2009. № 8. 3. 543-557

10. Savlukov A.I., V.M. Samsonov, R.F. Kamilov, E.D. Wakirova, R.N. YApparov, D.F. Wakirov. Sostoyanie ustoichivosti eritrocitov kak zveno adaptacii organizma// Medicinskii vestnik Bawkortostana, 2011. vol. 6. №4 p. 13-17

11. Sevast'yanov V.I., Laksina O.V., Novikova S.P., Rozanova I.B., Ceitlina E.A., Wal'nev B.I. Sovremennye gemosovmestimye materialy dlya serde4no-sosudistoi hirurgii, pod red. V.I. Wumakova, (medicina i zdravoohranenie, seriya hirurgiya, issue 2). M., VNIIMI, 1987 